\title{
A Comparative Evaluation of Alternative Blended Learning Models Used for Teaching Academic English (EAP/ESAP) to Students of Computer Sciences
}

\author{
Tatiana Kuzmina*, Tatiana Golechkova \\ Department of Business Informatics and Software Engineering, National Research University Higher School of Economics, 101000, \\ Moscow, Russia
}

\begin{abstract}
This paper describes the use of a number of alternative blended learning models based on a mixture of traditional face-to-face classes with some elements of e-learning in the course of "English for Academic Purposes" (EAP) and "English for Specific Academic Purposes" (ESAP) taught to junior and senior undergraduate students of computer sciences in the undergraduate program of Business Informatics and Software Engineering over a period of time from 2009 to 2012 at the National Research University Higher School of Economics (NRU HSE), Moscow, Russia. The following educational platforms for the imp lementation of blended learning models were chosen - Wiki (pbworks and wetpaint - -2009), sites and services Google ("BI HSE IELTS Class" 2009-2010) and a proprietary all university learning management system(LMS HSE LMS eFront - 2011-2012). The purpose of this study was to investigate the learning and pedagogical opportunities provided by each blended learning environment. The learners' attitude to bended learning environments and the problematic areas associated with academic skills development were detected by conducting a survey at the end of each EAP course. When working with senior years (ESAP) a number of Web 2 technologies were used and the most efficient ones were highlighted. The research outcome showed that despite some problems, students were satisfied with the pedagogical approach used and their academic achievements became significantly better due to online support.
\end{abstract}

Keywords Blended Learn ing, E-learning, Co mputer Sciences, Wiki, Google Sites, Learn ing Management System(LMS), Learner Autonomy

\section{Introduction}

\subsection{Blended Le arning}

In recent years, with the arrival of advanced Information Communication Technologies (ICT), numerous Web 2 tools and online services, blended learning emerges as the most distinguished instruction method in Higher Education, especially in teaching languages for specific and academic purposes (ESP/EAP). Diane Beltcher in her review[1] on trends in ESP/EAP emphasizes the increasing ro le of socially oriented perspectives and computer med iated communicat io $\mathrm{n}$ when outlining the 'Research Directions' for ESP Pedagogy' and the importance of blended genres.

Now it has become obvious that a weakness of traditional university courses are their lack of time flexibility, which requires learners to be present in class up to four times a week. This disadvantage becomes even more serious due to

* Corresponding author:

minats09@gmail.com (Tatiana Kuzmina)

Published online at http://journal.sapub.org/edu

Copyright (C) 2012 Scientific \& Academic Publishing. All Rights Reserved the fact that many traditional full-time students are now required to hold part-time jobs to support thems elves.

At the same time, the methods and principles of blended learning environment are based on the "assumption that there are inherent benefits in face-to-face (F2F) interaction as well as the understanding that there are advantages of using innovative on-line methods"[2]. John Wats on[3] emphasized the increasing convergence of online and F $2 \mathrm{~F}$ education and also stresses the role of tech-savvy teachers and technology coordinators in creating high quality instructions and content. He pointed out that there are a few definitions of blended learning which include:

- The integration of face-to-face and online learning to help enhance the classroom experience and extend learning through the innovative use of information and communications technology. Blended strategies enhance student engagement and learning through online activities to the course curriculum, and improve effectiveness and efficiencies by reducing lecture time.

- A course that blends online and face-to-face delivery. Substantial proportion of the content is delivered online, typically uses online discussions, and typically has some face-to-face meetings. The blended cours es have between 30 
percent and 79 percent of their content delivered online, with the remaining portion of the course content delivered by face-to-face instruction or other non web-based methods, such as paper textbooks.

- Blended learning refers to a mixing of different learning environments. It combines traditional face-to-face classroom methods with computer-mediated activities. There is no consensus on a single agreed-upon definition for blended learning and the terms "blended," "hybrid," and "mixedmode" are used interchangeably in current research literature [4].

Regardless of the definition of blended learning, it offers the possibility to significantly change how teachers and administrators view online learning in the F2F setting. According to Bonk and Graham[5], the main reasons for choosing blended learning are: (1) improved pedagogy, (2) increased access/flexibility, and (3) increased cost effectiveness. Thus, the improved pedagogy or more effective pedagogical practices are indicated above all reasons.

In the context of higher education in Russia, blended learning as well as other forms of online educational practices is relatively new, even though there is a steady growth in their popularity. The process of integration into higher education is not as fast as it could be due to the legacy of an old bureaucratic system. Nevertheless, in 2003[6] the Russian Federation (RF) joined the Bologna Convention[7] on higher education and this gave a powerful incentive to increase the quality of higher education in Russia and its competitiveness in the world. Along with harmonizing educational standards with those of the EU countries and other international communities, Russian universities started adopting new innovative pedagogical approaches which became mo re flexible and learner centered.

Thus, many universities took advantage of e-learning, distance learning, blended learning or other computer mediated practices. For example, in 2008 an online community Smart e-Learning Russia[8] with its own online journal e-Learning World[9] appeared. These and other online groups, communities[10],[11] and networks[12], [13],[14] join professionals, teachers, scholars and other specialists from the RF and other countries. They can take part in conferences and webinars, online teacher summits [15] share ideas; learn new skills and pedagogical approaches.

The analyses of recent publications on blended learning in Russia (both in higher education and schools) showed that some essential elements such as social bookmarks, educational networks and groups, services Google, W ikis, programmable media resources and even learning management systems (LMS) have already become a vital component of the educational process [16].

It should be noted that the authors and educators who already actively use different forms or elements of blended learning in Russia or abroad (Ukraine, Belorussia) emphasized in an online eTeacher Su mmit (March 2012)[17] that computers and the Internet fundamentally change nothing in the paradig $\mathrm{m}$ of learning, but have a significant impact on the method of information delivery to students. Students continue to master the material in courses; they attend tutorials and lectures as well as consolidate knowledge in the course of practical train ing and confirm it by doing tests. Some teachers specifically emphasized that blended learning environment increases the role of students' independent work while developing learners' autonomy. Such elements become the key to successful learning, but more importantly, these findings are in full compliance with the above mentioned Bonk and Graham's [5] reason (1).

The authors[16],[17] concentrated largely on the role of ICT in blended courses rather than on the outcome of the course itself, which, accord ing to Bonk and Graham[5], is of primary importance. As a result of such reflections, this study focuses mostly on the effectiveness of various alternative models of blended learning and specifically on successful learn ing factors that can be formed and enhanced during the course.

It is also worth mentioning that such an objective is a mong a few underlying principles of a modern concept of education adopted by HSE in 2010[18] when the university acquired the name NRU HSE. The new status made it possible for the university to gain more freedom in implementing the Bologna Conventions and in becoming a cutting edge of educational innovations in the Russian Federation (RF).

\subsection{Academic Contexts for EAP/ESAPStudents}

The course "English for Academic Purposes" (EAP) was designed for first and second year Bachelor's students of Business Informatics and Software En gineering Departments who are to take the academic module of International English Language Testing System(IELTS) examination[19] at the end of the second year of studies. The academic module of IELTS conducted by an external examination centre (BKC IH Moscow[20]) was included into the curriculum in 2010[21] after the university had gained a status of National Research University (NRU) with the commitment to adhere to international standards of teaching and learning languages set by the Common European Fra mework - CEFR[22]. Table 1 shows the mapping of the IELTS scale to the CEFR levels[23].

Table 1 outlines an approximate correlation between IELTS score and CEFR level. Taking into consideration that the initial CEFR level of NRU HSE students ranged from A2 to $\mathrm{B} 2$, the borderline for second year undergraduates was set at band 5 or above.

The 72-hour course "English for Specific Academic Purposes" (ESAP)[24] was designed for senior students. The course is aimed at helping Russian undergraduate students prepare for their final university exam in English in order to obtain the degree of Bachelor of Science in Software Engineering or Business Informatics. The exam tests a variety of skills including listening, speaking and academic writing, which involves preparing a 3000-word paper in English presenting the results of the student's graduation 
research project. Therefore, the course was designed combining elements of EAP and ESP, also known as ASAP (Jordan[25]), to help the students better prepare for the exam.

According to the university requirements, the target level at $\mathrm{BSc}$ is $\mathrm{B} 2+-\mathrm{C} 1$ on the Common European Framework [22]. In previous years the students already had achieved this level through 228 hours of the EAP course with elements of ESP (IT English) and Business English.

Table 1. Mapping of the IELT S scale to the CEFR levels

\begin{tabular}{|c|c|}
\hline IELT S score & CEFR \\
\hline $8-9$ & $\mathrm{C} 2+$ \\
\hline \multirow{2}{*}{7,5} & $\mathrm{C} 2$ \\
\cline { 2 - 2 } & $\mathrm{C} 1+$ \\
\hline \multirow{2}{*}{6,5} & $\mathrm{C} 1$ \\
\cline { 2 - 2 } & $\mathrm{B} 2+$ \\
\hline \multirow{2}{*}{5,5} & $\mathrm{~B} 2$ \\
\hline \multirow{2}{*}{4,5} & $\mathrm{~B} 1+$ \\
\hline 3 & $\mathrm{~B} 1$ \\
\hline
\end{tabular}

\subsection{Research Aim}

The aim of this research was to evaluate the effectiveness of some blended learning models used for teaching academic English to junior (EAP) and senior undergraduate students (ESAP) in the undergraduate program of Business Informatics and Soft ware Eng ineering Departments of NRU HSE over a period of time from 2009 to 2012. The research questions were set as follows:

A. What is the overall effectiveness of the blended model used?

B. What is the optimal share of an online and traditional F2F component in the blended model used?

C. Which academic skill poses the greatest challenge to be developed?

D. What online technologies prove to be most effective for developing academic skills?

\section{Research Methods - EAP}

Table 2. Overall Research Design for EAP Students

\begin{tabular}{|c|c|c|c|}
\hline \multirow{2}{*}{ Year } & \multicolumn{3}{|c|}{ Blended learning models } \\
\hline & $\begin{array}{c}\text { Total Number of Participants } \\
\text { (groups) }\end{array}$ & $\begin{array}{c}\text { Platform for Delivering } \\
\text { Online Syllabus } \\
\end{array}$ & Preparation for IELTS \\
\hline 2009 & $\begin{array}{c}41 \\
\text { (four groups) }\end{array}$ & Wiki - wetpaint/pbworks[26],[27] & --- \\
\hline 2010 & $\begin{array}{c}45 \\
\text { (four groups) }\end{array}$ & Google site-BI HSE IELT S Class[28] & 1 st year \\
\hline 2011 & $\begin{array}{c}47 \\
\text { (four groups) } \\
\end{array}$ & $\begin{array}{l}\text { lms.hse.ru-Development of Academic Skills for } \\
\text { IELT S-B2/C1 [29] }\end{array}$ & $2 \mathrm{~d}$ year \\
\hline \multirow{2}{*}{ April 2012} & \multirow{3}{*}{$\begin{array}{c}47 \\
\text { (four groups) }\end{array}$} & Research end & \multirow{2}{*}{$\begin{array}{c}\text { Paper format of academic } \\
\text { IELT S } \\
\text { administered by BKC IH }\end{array}$} \\
\hline & & all 47 participants sat IELT Stest & \\
\hline $\begin{array}{l}\text { May } \\
2012\end{array}$ & & \multicolumn{2}{|c|}{ IELT Sresults arrived from BKC IH } \\
\hline
\end{tabular}

The research methods for junior (EAP) and senior (ESAP) students were devised differently with the course objectives in mind. For EAP students the ultimate aim of the blended course was to take an academic module of IELTS with the score 5 or above by the end of the second year of studies whereas senior ESAP students aimed at passing their final university exam in ESAP at the end of the forth academic year. As a result of this, research methods for EAP and ESAP students are described in this paper separately in sections 2 and 3 respectively.

Blended learning models used for EAP students were a combination of traditional F2F classes with an Online Syllabus designed to meet course objectives as well as to develop students' autonomy and enhance cognitive learning. Each model was based on its own educational platform (Table 2). All EAP participants were junior students who took blended learning courses at the Department of Business Informatics and Software Engineering. The participants ranged in age from 17 to 19 years old. The initial level of English language competence of the participants who started preparation for IELTS (in 2010) ranged from A2 (one group of 11 students), B1 (two groups of 23 students in both) and B2 (one group of 11 students). The initial levels of language competence (CEFR[22]) were determined by a quick placement test which all participants took at the beginning of the academic year 2010 .

In 2011 two more B1 and B2 level students who moved fro mother departments of NRU HSE, jo ined in so by the end of the research 47 participants completed the course and took a paper format of IELTS in April 2012. The results of the test were issued by BKC IH and arrived in May 2012. The overall research design, number of participants and other data are shown chronologically in Table 2 .

Research questions A-C were answered with the help of online surveys (Dale T. Griffee[30]) which included points to address them. The research surveys were designed at the end of each course for data analysis as well as for quantitative evaluation of the blended model used.

\subsection{Research Design and Participants - EAP}


Answering research question $\mathrm{D}$ involved both qualitative and quantitative data analysis based on observations and reflections made over students' academic progress in the blended learning courses during each period of study. However, the main findings of the research were made only by the end of the blended course when all 47 participants took IELTS in April 2012 and official results issued by BKC $\mathrm{IH}$ arrived in May 2012. Quantitative analys is of IELTS scores obtained by the participants allowed evaluating their academic achievements as well as confirming findings made with the help of qualitative analysis.

\subsection{Data Collection and Analysis - EAP}

Data gathering was organized in the end of each blended learning course by posting a survey to all the participants taking the course. However, the numbers of the participants who took part in the surveys in 2009, 2010 and 2011 were 21, 22 and 21 accordingly, which was significantly lower than they could have been if all the participants had answered the survey questions. Nevertheless, according to[30], the survey research data is considered to be statistically viable if it is based on the participation rate of appro ximately $50 \%$ or over.

The surveys were designed specifically for each blended learning model shown in Table 1. Popular Survey Monkey site [31] was used for this purpose. All surveys included points addressing the research questions $\mathrm{A}, \mathrm{B}$ and $\mathrm{C}$.

They were as follows:

"Do you find blended learning useful? - Yes, No, Not

Really" - in relation to question A (usefulness of the blended learning)

"What is the optimal share of online component? -

$40 \%, 50-60 \%$ over $70 \%$ " - in relation to question B (share of online component)

"Which academic skill do you find the most difficult? - in relation to question $\mathbf{C}$ (skill which poses the greatest challenge).

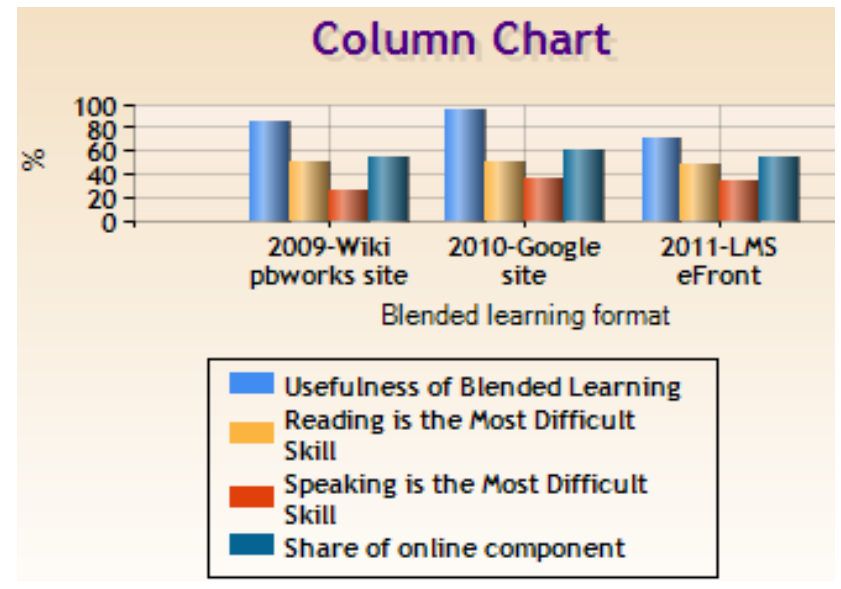

Figure 1. The participants answers (\%) to research questions A, B and C

Figure 1 below shows the average results of the quantitative survey analys is in relation to research questions $\mathrm{A}, \mathrm{B}$ and $\mathrm{C}$.
The Column Chart shows that the overall evaluation of blended learning models used within each period of research (2009 to 2011) was very positive with the figures accounting for a round $80 \%$ of 'Yes' ans wers (W iki-2009 and LMS-2011) and almost 98\% (Google site). The highest rate was given to Google site with its numerous services, functionality and other user-friendly features.

Question B - the optimal share of an online component in the blended model used, was assessed by the majority of the participants at 50\% in 2009 (W iki) and 2011 (LMS), whereas a higher figure of $60 \%$ is indicated by the majority of the participants using Google site (2010).

The last research question $\mathrm{C}$ indicated Reading and Speaking as the most difficult academic skills to be developed. Reading was consistently rated as the most difficult skill by approximately $50 \%$ of the participants whereas Speaking was rated by $25 \%$ of the participants using Wiki (2009), 40\% - using Google site (2010) and 38\% using LMS (2011). Other academic skills (Listening and Writing) were rated lower than Reading and Speaking as answering survey question $\mathrm{C}$ implied choosing only one multip le choice answer out of four.

Answering research question D involved qualitative analysis of pedagogical experiences accumulated over the whole period of study from 2009 to April 2012.

\subsection{Results - EAP}

The main research findings were revealed only when all the participants took IELTS in April 2012. Table 3 shows IELTS results of all the participants by groups and initial CEF [22] levels.

The last column in table 3 shows that all the participants made substantial progress of slightly over two levels up the CEF scale after they had completed blended courses. The greatest achievements were made by two students from the strongest group B2 (2010) who achieved C2 level (proficient user) and two students from the weakest group A2 (2010) who achieved B2+ level within less than two academic years of studies.

\subsection{Discussion - EAP}

On the whole, taking into consideration the results of the research presented in this paper as well as the IELTS scores obtained by the participants in the end (April 2012), the following research findings answering questions A-D were indicated:

A - students evaluated the effectiveness of blended learning models used within each period of research (2009 to $2011)$ very positively at (80-98)\%. The highest figure was given to Google site[28]. The latter can be explained by its full functionality, efficient services, openness and user-friendly interface. A newly introduced LMS eFront platform proved to be less popular (with approximately $70 \%$ of positive responses). This can be explained by its less user-friendly interface and some problems with connectivity due to a continuous process of its customization. 
Table 3. IELT S scores of the participants

\begin{tabular}{|c|c|c|c|c|c|c|}
\hline \multirow{3}{*}{$\begin{array}{l}\text { Number of } \\
\text { partisp in a } \\
\text { group }\end{array}$} & \multirow{2}{*}{2010} & \multicolumn{5}{|c|}{ April 2012} \\
\hline & & \multicolumn{5}{|c|}{ IELT S scores of all 47 participants (partisp) } \\
\hline & $\begin{array}{c}\text { Initial } \\
\text { CEF level }\end{array}$ & $\begin{array}{l}\text { Average IELTS } \\
\text { score in a group }\end{array}$ & $\begin{array}{c}\text { Number of } \\
\text { partisp }\end{array}$ & IELT S score & $\begin{array}{l}\text { CEF } \\
\text { level }\end{array}$ & CEF level progress \\
\hline \multirow{4}{*}{11} & \multirow{4}{*}{$\mathrm{A} 2$} & \multirow{4}{*}{5,7} & 3 & 5 & \multirow{4}{*}{$\begin{array}{l}\mathrm{B} 1+ \\
\mathrm{B} 2+\end{array}$} & \multirow{4}{*}{$\begin{array}{l}\mathrm{B} 2+ \\
\mathrm{A} 2 \pi\end{array}$} \\
\hline & & & 3 & 5,5 & & \\
\hline & & & 3 & 6 & & \\
\hline & & & 2 & 6,5 & & \\
\hline \multirow{4}{*}{12} & \multirow{4}{*}{ B1 } & \multirow{4}{*}{6,5} & 4 & 6 & \multirow{4}{*}{$\mathrm{B} 2+\mathrm{Cl}+$} & \multirow{4}{*}{$\begin{array}{l}\mathrm{C} 1+ \\
\mathrm{B} 1 \pi\end{array}$} \\
\hline & & & 5 & 6,5 & & \\
\hline & & & 2 & 7 & & \\
\hline & & & 1 & 7,5 & & \\
\hline \multirow{4}{*}{12} & \multirow{4}{*}{ B1 } & \multirow{4}{*}{6,5} & 1 & 5,5 & \multirow{4}{*}{$\begin{array}{l}\mathrm{B} 2 \\
\mathrm{C} 1\end{array}$} & \multirow{4}{*}{$\begin{array}{c}\mathrm{C} 1 \\
\mathrm{~B} 1 \pi\end{array}$} \\
\hline & & & 3 & 6 & & \\
\hline & & & 3 & 6,5 & & \\
\hline & & & 5 & 7 & & \\
\hline \multirow{4}{*}{12} & \multirow{4}{*}{ B2 } & \multirow{4}{*}{7,3} & 1 & 6,5 & \multirow{4}{*}{$\mathrm{C} 1 \mathrm{C} 2$} & \multirow{4}{*}{$\begin{array}{c}\mathrm{C} 2 \\
\mathrm{~B} 2 \pi\end{array}$} \\
\hline & & & 6 & 7 & & \\
\hline & & & 3 & 7,5 & & \\
\hline & & & 2 & 8 & & \\
\hline
\end{tabular}

$\mathrm{B}$ - the optimum ratio between the online component and traditional F2F classes in the blended models used was indicated by the majority of participants at $(50-60) \%$. This correlation is regarded as an optimum condition by the participants, which is generally in agreement with the second definition of blended learning cited in [3]: "courses have between 30 percent and 79 percent of their content delivered online". According to participants' preferences, such a proportion allows to make the best out of online and traditional F2F learning environ ments.

$\mathrm{C}$ - the majority of participants indicated Reading and Speaking as the most difficu lt acade mic skill to be developed. This fact suggests that learning and memorizing extensive academic vocabulary for IELTS poses the greatest challenge to the majority of participants.

$\mathrm{D}$ - links to the most effective Web2 technologies used in the blended models were selected and evaluated in the course of study by both participants and from pedagogical perspective. Many inefficient technologies were rejected or replaced by their more effective alternatives. The most useful ones are given on the sites Google[28], Wiki[26] or within materials on LMS eFront, which, however, is a closed system designed for university use only.

Taking into consideration participants high IELTS scores in April 2012 (two levels up the CEF scale) the evaluation of the most useful for developing academic skills Web2 tools appears to be the following:

http://www.scribd.com/ - reading skills

http://voicethread.com/ - speaking skills

http://quizlet.com/ - academic vocabulary

$\mathrm{http}: / /$ www.ted.com/ - listening skills

Participants did not point out any sites for developing academic writing skills as these were being developed within traditional settings (in class or as home assignments) since for the academic module of paper IELTS writing by hand is compulsory.

\section{Research Methods for ESAP Students}

\subsection{Research Design, Procedure and Participants - ES AP}

Exam preparation takes place both in the third and in the fourth years and the teachers are usually changed every year/ Therefore it was decided to use the case study framework, which is considered as part of qualitative research tradition[30]. The situation for the case study was described above and the main research question was "How to make final exam preparation more efficient using online tools within the blended learning approach". In the case study only final year students took part. Thus, in the academic years 2010/11 and 2011/12 the research involved 24 and 17 fourth year students respectively. In general, these are Russian learners aged between 19 and 21 .

The course was planned on the basis of a variety of data collection tools[32], including the results of the Needs analysis conducted at the beginning of the academic years 2010/11 and 2011/12 and Diagnostic test results. The latter was designed as a mock final exam since evaluation in EAP and ESAP should contain a simulation of tasks the students will have to perform[25], so that at the end of the course the results could be compared to the actual exam thus providing a measure for the evaluation of the case study outcome[30]. This comparison enabled us to assess the effectiveness of using the blended learning approach to teaching. The approach was considered successful if the grades gained by the students participating in the study increased significantly comparing to those of the mock exam at the beginning of the year.

The Needs analysis and Diagnostic test in both years showed similar students' priorities, which were the following:

1) offering visual support and clearly structured rules and requirements; 
2) studying academic style conventions;

3) improving accuracy through practicing proof-reading and editing;

4) broadening the range of cohesive devices;

5) studying paragraph structure;

6) organising ideas in paragraphs;

7) raising the learners' awareness of the necessity to avoid plagiarism;

8) using pairwork and groupwork to practise speaking;

9) studying exam requirements;

10) general revision of some grammar rules (articles, tenses, passive structures);

11) general consolidation of academic vocabulary.

It is obvious that all the points mentioned by the students cannot be covered in a 72-hour course. That was the primary reason for choosing the blended approach to teaching with Web 2 technologies. Since the students identified a whole range of problematic issues they wanted to focus on, it was decided to offer them a choice of online instruments to work on skills independently and at their own pace to ensure learner train ing [34] outside the classroom, thus developing their learner autonomy[35] and offering them maximum flexibility and learner-centeredness[34]. It was possible as, according to the questionnaires mentioned above, the students were highly motivated to gain high scores in their final exam and were prepared to work hard with appropriate guidance on the part of the teacher. This opportunity was offered by the online and mobile tools.

A wide range ofWeb 2 tools were used by the learners and here we will give only some examples, as web technologies evolve fast and new tools appear daily. To practice vocabulary (both academic and ESP) the students used Quizlet[36] and various flashcard applications in their mobile phones and laptops. Online voice recorders[Vocaroo, Audacity[37] helped learners record their talks and presentations in order to assess them individually or ask for the peers' opinion. Using online forums and blogs enabled the learners to share their written works and offer each other correction thus developing editing and proofreading skills. In order to visualize the covered materials, especially exam requirements, grammar rules and vocabulary sets, mind maps were designed and presentation software Prezi[38] was used. Finally, online grammar tests were offered to those learners who needed to revise and practice some grammar patterns. All other sub-skills, mainly associated with writing, were developed in traditional F2F setting, which proves to be most efficient for this particular reason.

\subsection{Data collection and analysis - ES AP}

We used end-of-course learner questionnaires to asses the learners perceived achievements and progress, as well as their satisfaction with the course content and the chosen teaching approaches[33, 39]; and conducted an informal discussion with students focusing on their feelings about the course and the way it was delivered. In addition, we calculated the difference in score between students' entry grades at the beginning of the year to those at the end shown in the exam.

\subsection{Results and Discussion - ESAP}

The comparison of the mock exam results to those in the real exam showed an average $29 \%$ increase in scores in 2011 and $35 \%$ in 2012 . This upward trend could be explained by the fact that each year the course is more adapted to learners' needs and lacks (Hutchison \& Waters[40]). Another important factor is that the learners gained high scores in the areas which were dealt with F2F only briefly and were mainly left for individual work using Web 2 tools.

Moreover, in the oral informal group discussion about $85 \%$ of learners mentioned the effectiveness of integrating Web2 tools into the course. The learners could feel their own progress and noted the development of their independence of the teacher.

The overall level of satisfaction with the blended version of the course was $97 \%$, which is largely accounted for by the use of Web2 and mobile learning technologies.

\section{Conclusions}

To sum up it is essential to emphasize a great cognitive, professionally-oriented and didactic potential of hybrid (blended) learning which exploits both advantages of traditional $\mathrm{F} 2 \mathrm{~F}$ classes and engages students in using various educational Web2 tools. These tools create not only a positive emotional background but also a learning environment customary for modern 'digital natives' who have access from any place as well as develop students' autonomy, critical thinking, self-esteem and independent decision-making. As a result, the use of these technologies in the format of blended learning helped enhance students' academic achievements significantly.

In relation to junior EAP students this conclusion becomes evident if we look at the participants' high IELTS scores in an external examination conducted by BKC IH[20]. Thus, the assumption of 'improved pedagogy and increased access/flexibility' made by Bonk and Graham[5] has been strongly supported by the research outcome.

Concerning the final years, it has been revealed that students exposed to blended learning not only showed higher levels of engagement and motivation, but also developed their learner autonomy and achieved good results by the end of the course.

However, after completion of the research, a number of shortcomings were revealed. They are related to the fact that all innovative approaches will be inevitably slowed down if there is the lack of enthusiasm, motivation and consistent involvement of teachers and students in the blended learning process. Therefore, in the absence of these factors, even though there is a high interest from the side of university administration in the context of a favorable educational policy of the country, the outcome of blended learning will always depend on the efforts of individuals - tech-savvy 
teachers, technology instructors and student coordinators.

Whatever the case, the efforts of teachers, instructors and students who already use the Web 2 tools in educational process need to be consolidated and grow into a more efficient form of discussion, sharing experiences and knowledge on a much broader scale than simply sending messages to the university admin istration or using university forum as well as a closed LMS eFront forum.

\section{ACKNOWLEDGEMENTS}

The authors wish to acknowledge the National Research University Higher School of Economics with the support of which the courses were designed.

\section{REFERENCES}

[1] Diane D. Belcher, Trends in teaching English for specific purposes, Annual Review of Applied Linguistics, Volume 24, Copyright 2004 Cambridge University Press, Printed in the USA, 2004.

[2] Clark Ian and P. James, "Blended learning: An approach to delivering science courses on-line" in Proceedings of the blended learning in science teaching and learning symposium, pp. 19-24, 2005.

[3] John Watson, Blending learning: The convergence of online and face-to-face education, The Promising Practices series, North American Council for Online Learning, USA, 2008.

[4] Online

Available :http://en.wikipedia.org/wiki/Blended_learning

[5] C.J. Bonk, Charles R. Graham, Handbook of Blended Learning: Global Perspectives, local designs. Pfeiffer Publishing, USA, 2004.

[6] OnlineAvailable:http://eng.yabloko.ru/Press/2003/9/030919 .html

[7] OnlineAvailable:http://ec.europa.eu/education/policies/educ /bologna/bologna.pdf

[8] Online Available:http://www.elearning-russia.ru/forum/ forum 2011/

[9] Online Available: http://www.elw.ru/

[10] Online Available:https://www.facebook.com/groups/EUE ducators/

[11] Online Available:http://www.britishcouncil.org/ru/russia. htm

[12] Online Available: http://www.linkedin.com/

[13] Online Available:http://conf.elearningpro.ru/?option=com content\&view $=$ article\&id $=16 \&$ Itemid $=18$

[14] Online Available: http://conf.elearningpro.ru/?page_id=6

[15] Online Available: http://www.elearningpro.ru/
[16] Alla L. Nazarenko., Bondarenko E ena V., Fandei Victoria A., Dugartsirenova Vera A. and Tatiana A. Kuzmina, Information Communication Technologies in linguistics, lingvodidactic and intercultural communication, Moscow University Book, Russian Federation, 2010.

[17] Online Available:https://docs.google.com/open?id=1Aw9 EZlk6Eo1w-YMk9sKa4c2930gRYQCII7ea4KIFYb3GdEvb HSkSt9yJHpK

[18] Online Available: http://www.hs e.ru/standards and http:// strategy.hse.ru/en/index.html

[19] Online Available: http://www.ielts.org/

[20] Online Available: http://www.bkcih-moscow.com/

[21] Online Available: http://www.hse.ru/docs/22510736.html and $h t t p: / / e c o n o m i c s . h s e . r u / r u / e n g / c o u r s e s$

[22] Common European Framework of Reference for Languages: Learning, Teaching, Assessment (CEFR): Modern Lan guages Division, CUP, Council of Europe, 2004.

[23] OnlineAvailable:http://www.ielts.org/researchers/common european_framework.aspx

[24] Online Available (In Russian):http://www.hse.ru/edu/courses /34468226.htm 1

[25] Jordan, R. R., English for Academic Purposes. Cambridge University Press. 2011.

[26] Online Available: http://kuzmina.pbworks.com

[27] Online available: http://minatsict4ilt.wetpaint.com/

[28] Online available: https://sites.google.com/site/bihseieltsclass/

[29] Online Available: http://lms.hse.ru/

[30] Dale T. Griffee, An Introduction to Second Language Research Methods: Design and Data, TESL-EJ Publications, USA, 2012.

[31] O n line Available:http://ru.survey monkey.com/My Surveys. asp $x$

[32] Richards, J., Curriculum Development in Language Teaching. Cambridge University Press. 2001

[33] Graves, K., Designing Language Courses: A guide for Teachers. Heinle \& Heinle Thomson Learning. 2000.

[34] Thornbury, S., An A-Z of ELT. Macmillan. 2010.

[35] Chan, V., Autonomous language learning: The teachers' perspective. Teaching in Higher Education, 8, 2003, 33-54.

[36] Online Available: http://quizlet.com/

[37] Online Available: http://vocaroo.com/andhttp://audacity. sourceforge.net/

[38] Online Available: http://prezi.com/

[39] Heigham, J. \& Croker, R., An Introduction to Qualitative Research in Applied Linguistics. Palgrave Macmillan. 2009

[40] Hutchinson, T. \& Waters, A., English for Specific Purposes: A Learning-centered approach. Cambridge University Press. 1987. 